\title{
Fear-of-Failure and Cultural Persistence in Youth Entrepreneurship
}

\author{
Comparative Analysis: Greece versus Germany
}

\begin{abstract}
This paper demonstrates the high sensitivity of youth's fear of failure to local culture, in terms of its persistence across space and its change (hysteresis) in times of economic shocks, which renders entrepreneurship a very dubious tool for tackling youth unemployment especially in times of crisis. The paper compares in particular the propensity to entrepreneurship among young people in Germany and Greece as a function of their fear-of-failure and its variation across space (Greece and Germany) and over time (before and after the crisis in 2007). Data from the Global Entrepreneurship Monitor (GEM) provides a pooled cross-section for the period $2003-2010$. We address the data using a probit model with year fixed effects. Regarding the influence of personal fear-of-failure, we find that youth between 15-24 years of age are less entrepreneurial in both Greece and Germany, while the 25-34 years old young adults in Greece are already at the same entrepreneurial level as an average adult. Our findings also support existing gender differentials in both countries, which generally phase out among young people. Yet, country differences in perceptions have the greatest impact on entrepreneurial propensity. Regarding the local cultural characteristics, there is evidence of cultural embeddedness and cultural persistence effects especially among youth between 15 and 24 years of age which makes entrepreneurship an unsuitable tool for handling youth unemployment especially for this age group.
\end{abstract}

Keywords: entrepreneurship, age differentials, gender disparities, embeddedness, cultural persistence, Greece, Germany

JEL classification: Z10, L26, D22 


\section{Introduction}

Following the Great Recession in 2007 and the subsequent economic crisis, which led to a huge surge of unemployment among young people in most European countries, entrepreneurship has been the focus of policy making attention as an eventual buffer against youth unemployment (EC, 2012; Crisp and Powell, 2016). This perception grew in parallel to the more classical view on entrepreneurship as an engine for local economic development in the EU countries and the social-mobility-related type of employment on individual level. The question raised is to what degree stimulating entrepreneurship is indeed a viable way out of the precariously high youth unemployment and its individual development aftermaths.

Our concerns stem from the observation that the European countries exhibit tendencies of varying intensity of involvement in entrepreneurial activity (see, among others, Minola et al. 2016). Moreover, we know that entrepreneurial propensity is transmitted across generations (Laspita et al. 2012). And this is perhaps the mechanism through which entrepreneurship remains relatively persistently similar levels in the same localities over different time periods (see Steyaert and Katz 2004; Fritsch and Wyrwich 2014, 2017a,b). So, it is reasonable to expect that youth entrepreneurship is bound to be found very differently spread across various countries i.e. across space in the same time period. Meanwhile, in different time periods the socio-economic conditions within a country vary (see Jessop, Young and Scherrer 2015; Tubadji, Angelis and Nijkamp 2016), so in times the same country may exhibit different propensities towards entrepreneurial activity than its habitual cultural attitudes would expect. This is due to the link between propensity to entrepreneurship and factors such as risk and uncertainty which are motivated by a general culturally sensitive attitude to fear of failure (see Wennberg, Pathak and Autio 2013). 
The focus of our analysis in the current study is to identify the factors behind the differences in the entrepreneurship of youth (age 15-24) and young adults (age 25-34) in the two most extreme economic cases of the recent economic crisis in Europe: Greece and Germany. We select these two countries first because of their stark cultural differences, which is very likely to have important bearing on their treatment of fear of failure. Greece is a highly ethnically and religiously homogenous country (Orthodox Christians over $90 \%$ of the population), a country that has for a large period of time dominated all its surrounding territories being the heir of the Roman Empire, and a territory where weather conditions are related to a warm climate that predisposes to optimistic attitudes. Germany is a country where two main religious streams have been traditionally in contestation (Protestant and Catholic), a country which historically is likely to view its neighbours as powerful claimants of its territory, a country where the cold climate predisposes more prudent and pessimistic attitude per se, for all of which the famous German Angst (fear) has been widely documented in the literature. Naturally, these are two countries with observed very different identities. They are also known for having very different levels of development of the entrepreneurial sector - Greece being the one of the two that is traditionally the natural long lasting leader in this activity. These two countries are therefore very suitable to provide clear identification for the cultural drivers behind the local differences in fear of failure across space that we would like to analyse. Second, during the recent crisis, Greeks have objectively much more unstable economic system, thus the attitudes to fear of failure are natural to have increased much more for them than the same attitudes in way more economically stable Germany in the same period of time. If there are no significant variations in the effects from the temporal and space differences in these two very different countries on entrepreneurship, we can regard entrepreneurship as a universal measure against youth unemployment. But on the other hand, if cross cultural and temporal differences in the factors affecting youth entrepreneurship are observed, those have to be taken into consideration when attempting 
to reach comparable results on youth unemployment across time and space with the same policy interventions.

We claim that there are: (i) differences in the average fear-of-failure of various groups between different countries (i.e. across space); and (ii) differences in the cultural attitudes (such as the attitude to fear of failure) within one and the same country over time. Both types of differences (spatial and temporal) count as valid factors for shaping individual entrepreneurial propensity of all ages in the said countries and youngsters are equally dependent on these factors (even if potentially with a different intensity than adults are). Therefore it is difficult to expect entrepreneurship to emerge as a miraculous Baron von Munchhausen solution for young people especially in countries with traditionally low levels of entrepreneurship per se. Moreover, we claim that in crisis periods the cultural attitudes may change and the magnitude of the change may vary across cultures. This means, we suggest that there are cultural space and time effects that hinder entrepreneurship from being a universal solution for youth unemployment.

Space-wise, we can compare Greece and Germany with a twofold objective: (i) to outline the role of age and other main socio-demographic factors for entrepreneurial activity in the two countries and (ii) to analyse the entrepreneurial persistence effect as a cultural-embeddedness driven economic process in a locality, as contrasted to the role of entrepreneurship as a buffer against unemployment in the years of crisis. We expect to find entrepreneurial cultural persistence - i.e. evidence for across-generational transmission of the propensity to entrepreneurship within the borders of the same country (Fritsch and Wyrwich 2014, 2017a,b) which will be associated with significant across space differences in entrepreneurial activity in Greece and Germany. Namely, we expect higher entrepreneurship among youth to be more strongly demonstrated in Greece, which is a traditionally entrepreneurial country. Descriptive evidence shows that established business ownership rates for young people in Greece are still much higher than the ones in Germany (see OECD 2015). There is however no scientific research, 
up to our knowledge, about the cultural persistence effects on entrepreneurship in Greece. We assume here that entrepreneurship is less likely perceived as a way-out-of-unemployment for young people in Germany than in Greece, due to a traditional difference in the levels of fear-of-failure in entrepreneurship across the two localities. We expect differences between the two countries to be less distinct in case of mature adults because the higher need for entrepreneurship among the young adults will reduce the role of cultural factors for them.

Time-wise, we expect to find evidence for cultural hysteresis, i.e. changes in the level and effect of cultural attitudes within the same country in different time periods especially distinct between periods of stability and periods under socio-economic crisis conditions. Cultural hysteresis is documented for both Greece and Germany on regional level (see Tubadji et al. 2016, Arrighetti et al. 2016). We expect that the fear-of-failure levels of individuals increase under economic crisis conditions, and we assume this is also valid for the groups in most precarious conditions, such as the youth under massive youth unemployment.

The remaining of the paper is structured as follows. Section 2 gives a summary of the literature on the main factors for entrepreneurship and the meaning of the persistence and hysteresis mechanisms in using entrepreneurial activity as a buffer against unemployment. The existing evidence from Greece and Germany on these issues is discussed and our main assumptions and expectations are summarized. Section 3 offers our empirical model that will be used to test our two working hypotheses regarding: (i) fear-of-failure as a factor for youth unemployment and (ii) its disparities across space and time. Section 4 presents our data, estimation methodology and findings. Section 5 offers concluding remarks and policy-making related interpretations. 


\section{Cultural Persistence and Cultural Hysteresis in Entrepreneurial Propensity}

\subsection{Standard Determinants of Entrepreneurship}

The vast literature on entrepreneurship has clearly sign posted the enormous significance of six determinants of entrepreneurial activity. These include two external factors: the investment as an input and the motivation (i.e. the role of incentives) and four main personal characteristics: skill (human capital), gender, age, and fear of failure (see excellent summaries in Carland et al., 1988; Fischer et al., 1993; Kourilsky and Walstad, 1998; Fischer and Nijkamp 2009; Baycan and Nijkamp 2012; Fafaliou 2012; Dvoulety et al. 2018).

Investment is clearly the economic input essential for the entrepreneurial success and is therefore one of the classical determinants in the Schumpeterian Quality Ladder Model (see Aghion and Howitt, 1992). Motivation is both a spring off of the availability of money and strive for profit but also a function of intrinsic drives for finding a purpose and expressing one's identity (see Schumpeter 1947; Frey 1997; Shane, Locke and Collins 2003). Never-the-less the economic success of a company is clearly a function of the investment available for it even if motivation can temper the way the investment is managed. The tempering is also not only driven by the motivation but quite likely by the skill of the entrepreneur as well. Skill (human capital) is a classical part of the endogenous growth model and is studied together with gender in great detail in entrepreneurial literature (see Brochhaus 1980; Blanchflower and Meyer 1994; Blanchflower 2004; Brandstaetter 2011). In particular skills are often contested as a factor for entrepreneurship (see Lukes and Zouhar 2013; Van der Sluis, Van Praag and Vijverberg 2008) while gender is clearly demonstrated to be strongly significant a factor, perhaps due to social constructs about the role of the woman in society, where women are expected to be less daring and more docile (see for example Simoes, Crespo and Moreira 2016). Age is found to be a very specific factor, which is initially having a growingly positive association with entrepreneurial activity, yet there is a turning point in this 
relationship generating an inverse U-shape curve (Blanchflower 2004; Caliendo, Fossen and Kritikos 2014). This is giving us a reason to expect important differences between the entrepreneurial behaviour of young and more mature generations. Fear of failure is a general attitude of fear which motivates both risk-aversion/risk taking preferences and uncertainty avoidance (Shapero 1982; Dubini, 1989; Zhao et al., 2010; Wennberg, Pathak and Autio, 2013) ${ }^{1}$. These factors have entire schools of thought dedicated to their study (such as the Austrian school or the New Economic Thinking school). Yet, what we are interested here are not the very risk avoidance and uncertainty avoidance but the basic culturally determined fear of failure effect on both of them.

So, our main interest in this study falls on the interaction between fear of failure and age, especially the young entrepreneurs. Modelling empirically the youth entrepreneurship however clearly requires to take into consideration the remaining main factors as important controls. Our main claim is that fear of failure is a more complex factor that needs further attention to be understood especially with regard to its relationship with culture.

\subsection{Culture, Fear of Failure and Entrepreneurship}

Fear of failure, whether expressed as risk attitude or attitude to uncertainty, always narrows down to a general attitude of fear of failure. Individual attitudes might have a self-determined unique component (see Shackle 1949) but they are to a very big extent known to be transmitted across generations and strongly influenced by role models and general characteristics of the local cultural context.

\footnotetext{
${ }^{1}$ The role of risk-avoidance has been propelled most seriously in the entrepreneurial literature by the classical tradition of the Austrian school and the Schumpeterian stream in it has paid particular attention to risk attitude as a source of propensity formation (Mise 1949, Klein 2008, Schumpeter 1934, Knight 1921 and Shackle 1949). Thus, firstly young people and young adults may be expected to have different propensity towards risk taking due to the time horizons considered (see Mather et al. 2012).
} 
Transmission across generations is the most immediate level of the family culture and attitudes being passed from parents to children. The relationship between parental entrepreneurial propensity (and occupational propensity per se) and children's entrepreneurial propensity is well documented in the literature (Kohn, Slomczynski and Schoenbach 1985; Lee 1999; Kind 2015; Sorger and Fritsch 2017). More generally, role models (outside the family) and the huge significance of their presence for entrepreneurial activity of the youth is a very well researched aspect (see for example Van Auken, Fry and Stephens 2006; Obschonka, Silbereisen and Schmitt-Rodermund 2011; Guerra and Patuelli 2014, Guiso et al. 2015; Wyrwich et al. 2016). And even more generally, the cultural context and embeddedness in the local networks (Rawls 1971; Kloosterman et al. 1991) are known to be important factors for entrepreneurial success. Also, the existing literature on embeddedness suggests that people operate largely bound within the limits of the average local attitudes and preferences (Hofstede 1983, 1984; Ajzen 1991) which can act as a shield for their survival as business entities (see Kloosterman and Rath 2001). In this way, given the same individual risk-taking propensity, a person embedded in a less risk-taking milieu will exhibit lower external preference for risk-taking than the same individual in a more risk-taking-friendly environment; hence, the embeddedness itself will decrease the risk of the enterprise and therefore people will be likely to adapt to the attitudes in their local cultural milieu (i.e. will tend towards an embedded behaviour). Some existing hybrid analysis of all these cultural levels show the simultaneous operation of the vertical (from the parents) and horizontal (from the network of peers) transmission of the cultural inclination towards entrepreneurial activity of young people (see for example Andersson and Koster 2011; Rodriguez-Pose 2013; Kibler et al. 2014).

Therefore, we are interested in analysing the individual's unique (self-reported) attitude to fear of failure as well as the contextual attitudes towards fear of failure as two dimensions of the overall fear of failure factor both equally deserving attention. The local attitudes to failure are likely to exhibit two characteristics: cultural persistence across space and cultural hysteresis over time. 


\section{$\underline{2.3 \text { Cultural Persistence Effects - Local Cultures across Space }}$}

The local culture is generally persistent within a locality, keeping a long-lasting memory of all history that has happened in the locality. Therefore, local cultures across space are found very different from each other and these differences are difficult to eradicate i.e. culture is strongly persistent in the locality where it has occurred. The local culture of entrepreneurial activity has been also very well documented in the literature (see Wyrwich et al. 2016; Fritsch and Wyrwich 2017)².

Empirical evidence shows persistence-wise that different ethnic backgrounds result into different occupational choices by immigrants and different types of entrepreneurial activity they enter into (Kerr and Mandorff 2015). Anecdotal evidence from the Netherlands also shows that some professions are closed for the immigrants and hence entrepreneurship is typically an immigrant activity centred only on the open professions, which is rather a de-facto than a de-jure segmentation of the market (see for example Kloosterman et al. 1999; Kloosterman and Rath 2001; Rusinovic 2008). This is, in a way, related to risk-avoidance, in the sense that, there is a higher uncertainty about the qualifications for top positions that require specific social capital and social behavior. Here risk avoidance individuals may have more trust in local population implementing these tasks due to occupation specific networks, and this might raise a barrier for certain professions or positions for foreigners. It is also plausible that a transmission of skills and occupations across generations and within genders is observed to exhibit persistent cultural effects. According to Massey (2016), historic quotas and skills selection of migrants are related. That could be especially relevant for Germany and the Gastarbeiter waves that are related to a special skill category and yet the ethnic origin of the biggest share of these immigrants (Greeks and Turks) is traditionally strongly entrepreneurial. This is also particularly relevant for both Greece and

2 Additionally, the literature on entrepreneurial propensity differentiates nascent entrepreneurs into need-driven and opportunity-driven ones (see Lückgen et al. 2004; Wagner 2005) and this distinction might be relevant especially in the case of youth unemployment where the need factor is expected to dominate. 
Germany now from the perspective of the current immigration waves into those countries from Asia and Africa. This transmission to the next generations from parents to offspring, as well as the memory for entrepreneurial culture, spread through generations in the localities (i.e. transmission on both personal and local levels) has gathered enough evidence in the regional economics literature, where it is termed as transmission (on individual level) or more often as persistence of the entrepreneurial propensity and activity (see Fritsch and Wyrwich 2012; Fritsch et al. 2012, Laspita et al. 2012).

Thus, from the point of view of the same period of time, local culture is a stable persistent factor that is difficult to change in the contemporaneous moment and that affects local propensities to entrepreneurship.

\subsection{Cultural Hysteresis Effects - Local Cultural Changes over Time}

Even though local culture is generally persistent in a locality, in some time periods local culture may still vary significantly from its usual levels, especially in cases of external shocks (such as economic crisis) which may even lead to new cultural trajectories in the locality. This variation of local culture over time is how cultural change happens and is called in the literature cultural hysteresis (see Tubadji, Angelis and Nijkamp 2016). The above implies that the impact of embeddedness might also be affected by the change in circumstances over time. The change in the economic circumstances in a locality may generate a change (even if perhaps to some degree smaller than the transmission of preferences for riskavoidance across generation within the same geographic area). Therefore, cultural hysteresis is expected to be observed in the overall behaviour and choices of an individual during economic crisis.

There is known in the literature yet another related mechanism called tunnel-vision effect. This is the mechanism causing a non-linear behaviour of people under an asymmetric decline in the individual in the context of local improvement for other people, leading to the activation of a protest activation in the 
individual, as contrasted to the deactivation of an individual who experiences a personal decline in the context of overall stability (Hirschman and Rothschild 1973) $)^{3}$. Put differently, under the same negative condition (being stuck at traffic), if one sees "light in the tunnel" for improvement for some individuals one is likely to fight for it oneself; if one sees everyone else is stagnated, this leads to apathetic behaviour of the same individual. This effect may be considered in the realm of cultural hysteresis, since we observe different sensitivity to the same economic trigger given a different contextual situation. In short, we attribute the abnormal sensitivity of preferences in a case of an economic crisis condition to the fact that the usual levels of risk-avoidance change temporarily in magnitude and even direction in a temporarily relative manner.

\subsection{What Is Known about Germany versus Greece}

The similarities and differences in the existing empirical results, with respect to the above factors in the case of Greece and Germany are well documented in the literature too. Previous research has identified that higher educational level plays a significant positive role in entrepreneurial propensity in Germany, which is not the case in Greece (Fritsch, Kritikos and Rusakova, 2012; Daskalopoulou and Liargovas, 2008). However, there is evidence that both countries have experienced gender inequality and inferior performance of women in entrepreneurship. Different argumentation for this, used in the literature, seeming gender similarity regarding propensity to entrepreneurship. In Germany, women are found to be more prone to avoid failure and therefore exhibit a less entrepreneurially active behaviour (see Furdas and Kohn 2010; Pelger 2011). In Greece, the reason behind the inferior performance seems to be the local perception for the role of the female, which has gradually evolved and is now less relevant for

\footnotetext{
${ }^{3}$ The interaction between employment status and risk of failure (reflecting the so called tunnel vision effect - i.e. the contextual effect on one's perspective of reality) can be exhibited in various ways: as over-proportional returns from entrepreneurial activity due to unemployment (see Lechmann 2013) or in local persistence of the entrepreneurial activity trend (see Audretsch, and Keilbach 2007; Fritsch, and Wyrwich 2012).
} 
young females, at least regarding their educational orientation, which is very similar to that of the males among the technical sciences (see Nina-Pazarzi and Giannacourou, 2005; Bitros and Karayiannis, 2008). Put differently, the existing empirical literature leads to the conclusion that for Germany the main reason behind entrepreneurial propensity is a link between psychological personality type and gender effects, while for Greece the reason lies in the embeddedness in the local culture of gender attitudes i.e. a sort of a persistent over time aggregate effect ${ }^{4}$. The above sources indeed confirm the existence of across space differences in entrepreneurial activity in Greece and Germany on average aggregate level. Yet, there is scant literature on the influence of age on entrepreneurship in the two countries. We find in the literature that certain transmission of entrepreneurial propensity across generations exists (see Laspita et al., 2012 for an interesting example) and there are some dissimilarities in the entrepreneurial propensity's intensity among different age groups (Pilkovaa et al., 2014). However, the literature bares little recent evidence on these matters from the countries of interest to us (especially in terms of a spatial and temporal between country comparison) and hence, our study aims to address this empty niche.

Based on the above, we may expect that Greek entrepreneurs are rather motivated by an embedded tradition of entrepreneurial activity, transmitted from generation to generation of restaurant and other small businesses owners, while Germans' propensity to entrepreneurship is more dependent on the overall labor market situation and the economic trend. These propensities have most likely been passed through generations forming a cultural persistence effect. Hence entrepreneurship can be only partly considered as a buffer against youth unemployment. Cross-checking the soundness of these expectations for young people in particular is the main aim of this study.

\footnotetext{
${ }^{4}$ Naturally, there might be a cultural endogeneity hidden in this relationship, as the self-perception of women might be culturally shaped and trasmitted from generation to generation. Yet the current data availability does not allow for an adequate exploration of this nexus.
} 
The focus on youth's propensity to entrepreneurship, as different from the average propensity, is a necessary approach here. Firstly, both social changes and variations in preferences due to age differences are observed. Secondly, given the reverse demographic pyramid in the EU, i.e. the so-called ageingproblem, young people growingly exhibit traits of a minority in the labour market in terms of market competitiveness and bargaining power ${ }^{5}$ (see Fioria et al. 2016). Thirdly, the recent economic crisis has obviously greatly affected especially young people throughout the huge unemployment wave generated. Therefore, the significance of entrepreneurship as a tool out of unemployment (i.e. social mobility based on higher risk taking behaviour) on the one side and as a way for social reproduction (based on vertical transmission, embeddedness and persistence of entrepreneurial history in a locality) on the other, is to be considered with the greatest attention in the case of young people It would be especially interesting to analyse these factors and mechanisms and their operation in the two economically and culturally different countries at the extremes of the economic performance in the recent economic crisis in Europe: Greece and Germany. Our interpretation of the above theoretical settings, in terms of youth's propensity to entrepreneurship in Germany and Greece, is presented in the next section.

\section{Youth Entrepreneurship and Fear-of-Failure: An Operational Model}

The essence of the considerations and mechanisms described in the previous paragraph can be narrowed down to the expression of propensity to entrepreneurship as a function of: personal characteristics, individual fear-of-failure and local culture in which the individual is embedded (see for example Remoundou et al. 2016 for the case of Greece), the last two factors being of special interest as an issue of further exploration in terms of their interaction with the youth category. The above can be summarized in the following main operational model (1):

\footnotetext{
${ }^{5}$ Mental health stability is also related to skills (see for example Dietrich 2012).
} 


$$
P E=\beta_{1} P C+\beta_{2} \text { Fear }+\beta_{3} \text { Embed }+\beta_{4} \text { Youth }+\beta 5 \text { Interactions_Youth }+e_{1}
$$

In equation (1) $P E$ stands for propensity to entrepreneurship, captured by the business ownership variable, $P C$ stands for the factor of personal characteristics including gender, age, educational level, Fear is a variable expressing directly the individuals' fear-of-failure as a barrier to entry into an entrepreneurial activity and Embed is a vector of attitudes describing the local cultural milieu according to the perceptions of the individual; Youth is a vector of two variables identifying youth between 15 and 24 and young adults from 25 up to 34 years of age. We will also explore the interaction between these two youth categories and the fear-of-failure as well as the local attitude variables, in order to understand their relevance for the young people in particular. The main assumption here is that young people may be more independent from the grasp of the local culture and might be more globalized citizens than the previous generations. Interactions_Youth is a vector of interaction terms between the two youth categories and: (i) fear of failure on the one hand; and (ii) the rest of the cultural attitudes in which the youth are embedded on the other. Control variables such as gender may also be relevant for interaction with the youth variables as known from the literature.

The three main hypotheses to be addressed using the above model are as follows:

H01 (fear-of-failure): Individual propensity to entrepreneurship among young people is a function of personal fear-of-failure.

HO2 (cultural persistence): The magnitude of the effect of fear-of-failure on entrepreneurial propensity of young people varies across space.

H03 (cultural hysteresis): The magnitude of the effect of fear-of-failure on entrepreneurial propensity of young people varies over time. 
The next section describes the precise operationalization of H01, H02 and H03 with the GEM dataset.

Details on the data and the estimation methods used for testing of our hypotheses are given in the following section.

\section{Data and Estimation Strategy}

\section{$\underline{4.1 \text { Data and Variables }}$}

Our analysis is based on the Global Entrepreneurship Monitor (GEM) ${ }^{6}$, in its Adult Population Survey part. The GEM dataset presents information on individual level. From there, we take the individual demographic characteristics and the personal cultural attitudes such as the perception of the locality towards entrepreneurship, and the personal fear-of-failure.

Our compiled final dataset, uniting the eight consecutive years (2003-2010), contains 57,724 individual observations, 15,938 from Greece and the rest 41,786 from Germany. The data is representative on a country level for each year ${ }^{7}$. Of these 7,936 individuals have been self-identified as currently, alone or with others, the owners of a business (those who selected 'Yes' in the variable 'ownmge' in the GEM dataset, when answering to question Q2A) and 5,155 as expecting to start (alone or with others) a new business (those who replied 'Yes' in the variable 'futsup' when answering to Q3A). We use these two groups of people in order to quantify two different dependent variable in our model - propensity to be

\footnotetext{
${ }^{6}$ The GEM dataset naturally includes many other countries. Trying to analyse the combination of local and individual factors we need to narrow down the heterogeniety at one side of the exploration because extensive heterogeniety on both levels will not allow the clear identification of the effects under analysis. We pick to narrow down the heterogeniety on the local level. For this purpose, we choose to compare the effect from two local contexts with distinct cultural differences that are likely to inspire very different culturally driven fear of failure. Meanwhile the countries are experiencing also different temporal modifications of their local fear of failire compared to themselves in past periods. If at a later moment similar clear combination of spatial and temporal differences can be identified clearly between any other two countries from GEM, our analysis can be replicated and triangulated regarding its wider generaliziability.

${ }^{7}$ Our analysis remains consistent as interpretation when we use the data weighted for representativeness and on a pure individual observations basis. We report the latter because when dealing with individual preferences, one cannot reliably argue that an individual preference cannot be readily translated a sthe preference of the statistical category she/he represents, i.e. the classical measurement and aggregation challenges in quantifying utility and attitudes. Meanwhile the number of observations is large enough to provide statistical reliability of the estimations.
} 
an owner of an entrepreneurial activity (based on 'ownmge', labelled by us 'entr_owner') and potential nascent entrepreneurs (based on 'futsup', labelled by us 'entr_newpl'). .

The $P C$ vector of personal characteristics in equation (1) is quantified on the basis of self-reported gender and level of human capital. Human capital, in particular, is based on the GEM variable GEMEDUC, reporting harmonized educational attainment categories among interviewees, such as: None, Some secondary, Secondary degree, Post secondary, Graduate experience and N/A (Cannot code). Our dummy variable hc_gem is equal to 1 when the individual has selected the answer Post secondary or Graduate experience; when the answer to the question is N/A the observations are excluded from estimations. Fear is the personal fear-of-failure for an eventual entrepreneurial activity and is quantified with a dummy variable equal to 1 if the interviewee has answered 'Yes' to the GEM question Qi4: "Would fear-of-failure prevent you from starting a business?". Embed is the level of embeddedness of the choice in local context which is quantified with a dummy variable equal to 1 when the interviewee has answered 'Yes' to the GEM questionnaire entry under Qi6: "Do, in my country, most people consider starting a new business a desirable case?". Youth is an explanatory factor quantified with a dummy variable which is equal to 1 for a person in the 15-34 age group, based on self-reported current age (in years) (answering to GEM variable DEMB). As we have available the exact age, we later regroup the youth category into sub-groups. Namely, we create three alternative categories of youth: 15 - 34 years of age, in order to encompass the whole population which may be considered young under the current ageing Europe conditions; 15 - 24 years old, as this is the standard EU definition; and the remaining 25 - 34 years old. In this way we may control for any unwanted heterogeneity within the 15-34 years of age in each country. Being between 15 and 34 years of age creates a relevant broader definition of youth (see Dietrich 2012); however, the EU policies and programmes for young people and entrepreneurship tend to be targeted towards those below 25 years of age; meanwhile, young people below 25 and young adults between 25 
and 34 years of age are two groups that may be expected to have significantly different economic behaviour and preferences due to their different level of experience and independence.

\subsection{Estimation Strategy}

The estimation strategy we adopt here includes a regression analysis with a pooled cross section. Model (1) is used to explain the factors for business ownership separately in Greece and Germany. The particular entrepreneurial propensity differences of the youth categories between 15-24 years of age and young adults 25-34 are examined in contrast to the overall behaviour in the country. There are three main objectives outlining the aim of estimating this OLS with pooled data, namely:

1) To find out whether the fear-of-failure variable affects the business ownership by young people - which is a direct test of our H01;

2) To identify whether the young people have a different sensitivity towards the fear-of-failure across different localities - Germany and Greece. This test is captured by the comparison of the size of the coefficients for the interaction terms between the fear-of-failure variable (labelled for brevity fear) and the youth categories variables that the estimations generate for Greece and Germany respectively;

3) To establish whether the crisis period is associated with time differences in fear-of-failure among young people within the same locality, captured by dividing the sample in pre and post crisis parts and running the same estimations with the two datasets in order to compare the stability of the results obtained in the two periods.

In addition, we control for the known in the literature gender gap in entrepreneurial propensity, with special focus on youth (captured again by the interaction term between the gender and youth category dummy variables). Moreover, we delve into the eventual effects from local cultural embeddedness that might be explaining the entrepreneurial propensities in Greece and Germany - this is captured by a set 
of local attitudes and their interaction with the youth categories of interest. The next section presents our results.

As a pooled cross section is used, fixed effects (for year) are employed in our estimations. The results are presented in the next section.

\section{Results}

\subsection{Descriptive Statistics of the Main Variables of Interest}

We first have a look at the statistics regarding the main variables in our pooled datasets for Greece and Germany. Table 1 below presents this information:

$$
\text { +++ Insert Table } 1 \text { about here +++ }
$$

As seen from Table 1, the business ownership among individuals amounts to about $21 \%$ in Greece but to only about half of this $(11 \%)$ in Germany. The same big difference in general entrepreneurial propensity among people from Greece and Germany is also reflected in the nascent entrepreneurial intensity - which comes up to $14 \%$ in Greece and only $8 \%$ in Germany. The higher percentage of business ownership in Greece then can be expected to be likely explained by the inherited ownership of small businesses on the one hand. On the other hand, a reason for the higher entrepreneurial intensity in Greece could be the higher entrepreneurial culture which is revealed by the higher propensity to open new businesses. These statistical characteristics are consistent with the literature on entrepreneurial intensity in Greece and Germany (Daskalopoulou and Liargovas, 2008; Fritsch, Kritikos and Rusakova, 2012) The average age of both samples is between 40 - 45 years of age and the percentages of young people covered reflect the age pyramids of the countries under analysis and are comparable. Interestingly, the pooled dataset shows that fear-of-failure is experienced by $56 \%$ of the population in Greece and only $41 \%$ of the population in Germany. This supports the likelihood of our hypothesis 
regarding cultural persistence evident in the current differences in local cultures across space to hold true. We are very careful when interpreting these numbers, however, because our dataset contains pre and post crisis data for Germany and Greece (the 2007 crisis). Therefore, we must have a more detailed look into the country and time dimension of our data, as well as into the particular relationship of the crisis with the youth which is the main age category of interest in this analysis. Table 2 provides this deeper look into the data.

\section{+++ Insert Table 2 about here +++}

Table 2 shows that locally over time the percentage of people who expressed fear-of-failure as important in their decision making with regards to business ownership is relatively stable. This means that the impact of this factor on decision making might have changed over time (as cultural hysteresis would suggest) but this it so, it would be due to intensity of the fear, because the number of people who consider fear as significant for them has remained relatively stable. Also, these descriptive statistics mean that fear-of-failure is a relatively stable explanatory variable also for our pooled cross-section. To descriptively explore the level of the significance of the fear-of-failure across different localities we introduce Table 3 which shows the correlation between fear-of-failure and business ownership in Greece and Germany.

\section{+++ Insert Table 3 about here +++}

Table 3 adds to our understanding that while the number of people expressing fear-of-failure in Greece is larger than in Germany, the fear-of-failure intensity is higher in Germany. This comes obvious since fear-of-failure in Germany is associated with -0.18 negative correlation coefficient with business ownership, while in Greece the negative correlation between fear and actual entrepreneurial ownership is only -0.08. Furthermore, age-wise, both youth categories in Germany are more often associated with 
fear-of-failure than the same youth categories in Greece. These are interesting pointers towards fear-offailure being a more significant factor for entrepreneurial propensity of young people only in some places across space. Youth compared to elder people in their societies seem to be relatively lower which is in line with the existing literature (Blanchflower 2004; Caliendo, Fossen and Kritikos 2014).

Next, having obtained a fairly clear general idea about the differences in the levels of business ownership and fear-of-failure across Greece and Germany and young people's involvement in this context, we proceed with examining the relationship between these variables in greater detail. Below, we will provide some insight into the general importance of fear-of-failure as a factor for business ownership and its relevance to young people in particular, as well as into the variations of its impact across space and time.

\subsection{Fear-of-Failure as a Factor for Entrepreneurial Propensity among Young People}

Table 4 presents the results for Greece and Germany as two separate specifications of the same model.

$$
\text { +++ Insert Table } 4 \text { about here +++ }
$$

The results show that fear-of-failure is definitely a negative factor for business ownership in both countries, just as the literature predicts (Wennberg, Pathak and Autio, 2013). What we can further reveal here is that young people are per se less involved in entrepreneurial activity in both countries, especially in the youngest age bracket 15-24 years of age. On the one hand this is in line with the general finding in the literature that entrepreneurial activity grows with age (Blanchflower 2004; Caliendo, Fossen and Kritikos 2014). On the other hand, we can further read in these results a 'shielding effect' of education for young people from entrepreneurial activity, which we find is much stronger in Germany. The young 
adults in Greece seem to have the same likelihood to be business owners as the adults, but in Germany the young remain still disconnected from business ownership also after 25 years of age.

More importantly, fear-of-failure does not seem to be an especially youth-specific characteristics. The only significant interaction detected between fear-of-failure and age category concerns the youngest group 15-24 in Germany. All other age groups exhibit the same attitude to failure as the adults. This, in effect, means that youth entrepreneurship reflects the social construct about entrepreneurial involvement prevailing in their locality, rather than youth being themselves more or less afraid of failure as a entirely different new generation. It also means that the differences found in entrepreneurial activity between young and elder people is likely to be explained by the available resources and other objective factors rather than significant age-group-specific subjective risk taking inclinations.

The fear-of-failure differences across space and their relationship with the local culture the young people are embedded into is explored in more details in the next sub-section.

We should also note that our results confirm the gender gap in entrepreneurship that is known in the literature (Nina-Pazarzi and Giannacourou, 2005; Bitros and Karayiannis, 2008; Furdas and Kohn 2010; Pelger 2011; Simoes, Crespo and Moreira 2016) and furthermore our results show that this gap is wider among young individuals. The usually expected role of human capital (see Lukes and Zouhar 2013; Van der Sluis, Van Praag and Vijverberg 2008) is also recorded in our results. The direction of this effect seems to differ across countries which adds an interesting insight on the recorded differences in the literature with regard to the direction of human capital effect on entrepreneurship per se.

In short, our model is consistent with the literature and adds some insight on the youth-specific differences in entrepreneurial activity and fear of failure between generations within Greece and Germany and across places. We ask next the question to what extent these differences are product of cultural persistence and to what extent it is the crisis period that makes a difference for young people in specific to be entrepreneurially proactive in Greece and in Germany. 


\subsection{Fear-of-Failure Differences across Space: Cultural Persistence}

We focus here on the results of Table 4 above, from the perspective of their differences regarding the cultural embeddedness of young people in Greece and Germany.

This specific aspect of our results reflects the importance of the general local cultural attitudes for the business ownership predisposition and their interaction with the youth categories under investigation. We find that the cultural milieu in general is highly associated with the business ownership. Greece and Germany register completely different levels of importance of this attitude in terms of its marginal effects on the likelihood of business ownership. This means that while cultural embeddedness is at stake in both countries and influences the likelihood of business ownership, the local culture that the people in these two countries are embedded into is quite different and this is what drives the difference in their entrepreneurial pro-activeness. These findings seem to be valid for the societies as a whole and young people do not make a specific difference.

These findings clearly confirm that the differences in youth involvement with entrepreneurship in Greece and Germany stem from both the local culture these young people are embedded into and the general cultural differences behind the locally specific fear-of-failure and are not associated with the young people themselves. Put differently, young people's propensity to entrepreneurship is explained by the cultural environment in which these young people live, and not necessarily by their own personal characteristics (inclinations/preferences). Entrepreneurship in Greece and Germany seems to be transmitted across generations in a culturally persistent manner and to be the main cultural drive for the differences in entrepreneurial differences across space. These findings are in line with the general cultural persistence literature (Acemoglu and Robinson 2012) and the entrepreneurial persistence 
literature (Fritsch and Wyrwich 2014) and lead to the conclusion that we cannot reject our cultural persistence hypothesis.

\subsection{Fear-of-Failure Differences across Time: The Crisis Effect and Cultural Hysteresis}

In this last sub-section, we focus on the differences of the impact of fear-of-failure on propensity to entrepreneurship across time, and especially in the period following the economic crisis of 2007. Although the crisis is assumed by the institutions to be associated with an increased interest by youth entrepreneurship as a way out of poverty and unemployment, our results paint a different slightly picture of the reality, where an important aspect of the crisis is becomes salient - namely, its effect on cultural hysteresis of the young in particular. More specifically, the crisis seems to have caused an increased fear-of-failure (especially among unexperienced individuals) of entering into private investments and risky undertakings. Table 5 presents our results for model (1) before and after the crisis in 2007.

+++ Insert Table 5 about here +++

The results demonstrate that fear-of-failure was actually insignificant as a factor for entrepreneurship in Greece before the crisis of 2007 and it turned into an important factor only after this crisis. In Germany, on the contrary, the crisis did not affect much the importance of this factor.

The findings about the cultural attitudes in Greece also show that the local cultural milieu lost its grip on the individuals during the crisis as the positive effect from all the cultural attitudes decreased in magnitude after 2007. In Germany, on the other hand, the situation did not change. These results are interesting because 2007 was more important as a year of crisis in Germany rather than Greece. Yet, it seems that the cultural hysteresis effect has developed more prominently in the entrepreneurially more involved (and perhaps therefore perhaps more sensitive to the crucial for the entrepreneurship changes in the environment) country - Greece. 
These results are fully consistent with the expectations for existence of a cultural hysteresis during the crisis as found in the original paper on the topic by Tubadji, Angelis and Nijkamp (2016). Meanwhile, our results show the novel insight that the level and direction of the hysteresis during the same economic crisis was different in different localities. Thus, adding a cultural relativity aspect to the cultural hysteresis effect and perhaps to the general literature on hysteresis in economic processes (see Martin, 2012; Martin et al., 2016).

\section{Discussion and Conclusions}

The main purpose of this paper was to find out whether youth can be expected to be equally easily stimulated to enter into entrepreneurship across different localities. Using a model of entrepreneurial propensity that behaves consistently with the existing findings in the literature, our study adds some important insight on the role of local cultural embeddedness and its persistence across space as well as its sensitivity over time (especially in times of crisis) especially for the entrepreneurial activity of young people.

The persistence-in-space effects are confirmed by our findings. We find youth in Greece are much more often involved in business ownership than their German counterparts, and we find the main reason for this is related to the fear-of-failure possessed by the individual. Moreover, we find that fear-of-failure is only a locally specific characteristics which does not vary age-wise within a locality.

The cultural hysteresis across time is an effect that is clearly recorded by the data and is reported in our results. Interestingly, this time effect is both culturally relative (i.e. different within different cultures) and varies across age groups. The Greeks not only experienced a stronger cultural hysteresis after the 
2007 crisis, but also the youth were the ones who showed more sensitivity and even changed their degree of local embeddedness after the crisis.

Put differently, we find that entrepreneurial propensity is definitely related to one's fear of failure, but the latter has a different impact on one's propensity to become an entrepreneur across different localities. Moreover, different localities may exhibit different level of stability in terms of this attitude (fear-offailure) during economic crisis periods.

These findings on the one hand add a novel insight to the existing literature on cultural hysteresis clarifying its group-wise heterogeneity. On the other hand, these results are especially relevant for policy makers, since they show that young people are not only exposed to different local cultural traditions that drive them to different propensity to entrepreneurship per se, but also the reaction of the youth from different localities to the same crisis is likely to be different. Thus a universal policy measure for all youth across the EU is not likely to generate consistent results across space.

Thus, the policy implications of this study may be broken down to the following main takes. Business ownership levels among young people cannot be expected to differ significantly from the overall levels of entrepreneurship in the country of origin. Moreover, these levels of entrepreneurship are not likely to increase under economic crisis conditions because fear-of-failure is a main negative driving factor for entrepreneurial propensity among people per se, and it is rational for fear-of-failure to increase during economic crisis. Therefore, job creation and placement will most likely be a more successful treatment for youth unemployment than expectations for a boost in youth entrepreneurship during the high youth unemployment period. Under crisis conditions, the policy maker will have first to counter the negative effects from cultural hysteresis in order to manage to maintain the entrepreneurial propensity of young people up to the regular levels from the periods of normal economic circumstances. Our data reports even a negative effect of grants for entrepreneurship and business ownership, which can be explained by the cultural persistence (since not grants but inheritance drives ownership in the countries under 
investigation). An alternative explanation could be that business owners are more often for profit rather than for need entrepreneurs. In both cases, it seems unreasonable to expect entrepreneurship of young people to solve the big youth unemployment problem, and this is due both to the effect of cultural persistence and cultural hysteresis in the realms of entrepreneurial propensity.

\section{References}

Acemoglu, D., and J. Robinson (2012) Why Nations Fail: The Origins of Power, Prosperity and Poverty. 1st ed. New York: Crown, 529.

Aghion, P. and P. Howitt (1992) A Model of Growth Through Creative Destruction, Econometrica, 60(2): 323-51.

Ajzen, I. (1991) The theory of planned behaviour. Organizational Behavior and Human Decision Processes, 50 (2), 179-211.

Akerlof, G.A. (1997) Social Distance and Social Decisions. Econometrica, 65(5): 1005-1027.

Andersson, M. and Koster, S. (2011) Sources of persistence in regional start-up rates-Evidence from Sweden, Journal of Economic Geography, 11: 179-201.

Arrighetti A, Caricati L, Landini F, Monacelli N (2016) Entrepeneurial Intention in the Time of Crisis: A Field Study. International Journal of Entrepreneurial Behavior \& Research 22(6): 835-859.

Audretsch, D. and M. Keilbach (2007) The Localization of Entrepreneurship Capital - Evidence from Germany, JENA Economic Research Papers No. 2007 - 029.

Axelrod, R. (1997) The Dissemination of Culture: A Model With Local Convergence and Global Polarization. The Journal of Conflict Resolution, 41(2): 203-226.

Baycan, T. and P. Nijkamp (2012) A Socio-economic Impact Analysis of Urban Cultural Diversity: Pathways and Horizons, in P. Nijkamp, J. Poot and M. Sahin (eds.) Migration Impact Assessment: New Horizons, Edward Elgar, Cheltenham, UK.

Bitros, G. and A. Karayiannis (2008) Entrepreneurial Morality: Some Indications from Greece, Munich Personal RePEc Archive, Working Paper 13837.

Blanchflower, D. G. (2004) "Self-employment: More May not be Better." Swedish Economic Policy Review 11 (2): 1574.

Blanchflower, D. G., and B. D. Meyer (1994) "A Longitudinal Analysis of the Young Self-employed in Australia and the United States." Small Business Economics 6 (1): 1-19.

Bitros, G. and A. Karayiannis (2008) Values and institutions as determinants of entrepreneurship in ancient Athens, Journal of Institutional Economics, 4(2): 205-230.

Brixy, U. and M. Murmann (2016) The Growth and Human Capital Structure of New Firms over the Business Cycle, Discussion Paper No. 16-079. 
Brandstätter, H. (2011) “Personality Aspects of Entrepreneurship: A Look at Five Meta-analyses,"Personality and Individual Differences 51 (3): 222-230.

Caliendo, M., F. Fossen, and A. S. Kritikos (2014) "Personality Characteristics and the Decisions to Become and Stay Self-employed," Small Business Economics 42 (4): 787-814.

Carland, J. W., Hoy, F. \& Carland, J. A. C. (1988), "Who is an Entrepreneur?" Is a question worth asking, American Journal of Small Business, 12(4), 33-39.

Crisp, R. and R. Powell (2016) Young people and UK labour market policy: A critique of 'employability' as a tool for understanding youth unemployment, Urban Studies, 1-24, doi: 10.1177/0042098016637567.

Daskalopoulou, I. and P. Liargovas (2008) Regional and Sectoral Location Patterns of New Firms: The Case of Greece, Regional and Sectoral Economic Studies Vol. 8-2: 99 - 111.

Dietrich, H. (2012) Youth Unemployment in Europe- Theoretical Considerations and Empirical Findings, Friedrich Ebert Stiftung Study.

Dubini, P. (1989) The Influence of Motivations and Environment on Business Start-ups - Some Hints for Public Policies, Journal of Business Venturing, 4(1): 11-26.

Dvoulety, O., M. Mühlböck, J. Warmuth and B. Kittel (2018) 'Scarred' young entrepreneurs. Exploring young adults' transition from former unemployment to self-employment, Journal of Youth Studies, 21(9): 1159-1181.

Fafaliou, I. (2012) Students' propensity to entrepreneurship: an exploratory study from Greece, International Journal of Innovation and Regional Development, 4(3-4):.

Fioria, F., F. Rinesib, D. Spizzichinob, G. Di Giorgiob (2016) Employment insecurity and mental health during the economic recession: An analysis of the young adult labour force in Italy, Social Science \& Medicine 153: 90-98.

Fischer, M., and P. Nijkamp (2009) Entrepreneurship and regional development, VU University Amsterdam - Faculty of Economics, Business Administration and Econometrics. Series Research Memoranda 0035.

Fischer, E.M., A.R. Reuber and L.S. Dyke (1993) A Theoretical Overview and Extension of Research on Sex, Gender, and Entrepreneurship, Journal of Business Venturing, 8(2): 151-168.

Frey, B. (1997), Not Just for the Money, Edward Elgar, Northampton.

Fritsch, M., A. Kritikos and A. Rusakova (2012) Who Starts a Business and Who Is Self-Employed in Germany, DIW Discussion Paper 1184.

Fritsch, M. and Wyrwich, M. (2017) The Effect of Entrepreneurship on Economic Development-An empirical analysis using regional entrepreneurship culture, Journal of Economic Geography, 17: 157-189.

Fritsch, M. and M. Wyrwich (2012) The Long Persistence of Regional Entrepreneurship Culture: Germany 1925-2005, JENA Economic Research Papers No. 2012 - 036.

Fritsch, M. and M. Wyrwich (2014): The Long Persistence of Regional Levels of Entrepreneurship: Germany 1925 to 2005. Regional Studies, 48, 939-954.

Furdas, M. and K. Kohn (2010) What's the Difference?! Gender, Personality, and the Propensity to Start a Business, IZA DP No. 4778 
Guerra, G. and R. Patuelli (2014). The Influence of Role Models on Immigrant Self-Employment: A Spatial Analysis for Switzerland. International Journal of Manpower 35 (1/2): 187-215.

Guiso, L., L. Pistaferri and F. Schivardi (2015) Learning Entrepreneurship from Other Entrepreneurs? NBER Working Paper Series, Working Paper 21775.

Helmers, C., M. Rogers and P. Schautschick (2011) Intellectual property at the firm-level in the UK: the Oxford firmlevel intellectual property database, Discussion Paper Number 546, Department of Economics, Oxford University.

Hirschman, A. and M. Rothschild, (1973) The Changing Tolerance for Income Inequality in the Course of Economic Development, The Quarterly Journal of Economics, 87(4): 544-566.

Hofstede, G. (1984) National Cultures and Corporate Cultures, in: L.A. Samovar and R.E. Porter (eds), Communication Between Cultures, Belmont CA: Wadsworth, pp. 51-63.

Hofstede, G. (1983) National Cultures in Four Dimensions, International Studies in Management and Organization 13(1/2), 46-74.

Huggins, R. And P. Thompson (2015) Culture and place-based development: a soci-economic analysis. Regional Studies, Special Issue on Urban and Regional Horizons, 49(1): 130-159.

Jessop, B., B. Young and C. Scherrer (eds.) (2015) Financial Cultures and Crisis Dynamics, New York: Routledge.

Kerr, W. and M. Mandorff (2015) Social Networks, Ethnicity, and Entrepreneurship, NBER Working Paper No. 21597.

Kibler, E., Kautonen, T., \& Fink, M. (2014) Regional social legitimacy of entrepreneurship: Implications for entrepreneurial intention and start-up behavior, Regional Studies, 48(6), 995-1015.

Kind, M. (2015) Start Me Up: How Fathers' Unemployment Affects Their Sons' School-to-work Transitions. Essen: RWI-Leibniz-Institut für Wirtschaftsforschung, Ruhr-University Bochum, TU Dortmund University, University of Duisburg-Essen. No. 583.

Klein, P. (2008) Opportunity Discovery, Entrepreneurial Action, and Economic Organization, Strategic Entrepreneurship Journal, 2(3): 175-190.

Kloosterman, R. and J. Rath (2001) Immigrant entrepreneurs in advanced economies: mixed embeddedness further explored. J Ethn Migr Stud,27(2):189-201.

Kloosterman, R., Van Der Leun, J. and J. Rath (1999) Mixed embeddedness: (in)formal economic activities and immigrant businesses in the Netherlands, Int J Urban Regional Res,23(2):252-266.

Kloosterman, P. (1991). Beliefs and achievement in seventh grade mathematics. Focus on Learning Problems in Mathematics, 13(3), 3-15.

Knight, F. (1921) Risk, Uncertainty, and Profit, Boston, MA: Hart, Schaffner \& Marx; Houghton Mifflin Co.

Kohn, M. L., K. M. Slomczynski, and C. Schoenbach (1985) "Social Stratification and the Transmission of Values in the Family: A Cross-national Assessment." Sociological Forum 1 (1): 73-102.

Kourilsky, M.L. and Walstad, W.B. (1998) Entrepreneurship and Female Youth: Knowledge, Attitudes, Gender Differences, and Educational Practices, Journal of Business Venturing, 13(1): 77-88.

Laspita, S., N. Breugst, S. Heblich and H. Patzelt (2012). Intergenerational Transmission of Entrepreneurial Intentions. Journal of Business Venturing, 27(4): 414-435. 
Lechmann, D. (2013) Can working conditions explain the returnto-entrepreneurship puzzle?, Diskussionspapiere, Universität Erlangen-Nürnberg, Lehrstuhl für VWL, insbes. Arbeitsmarkt- und Regionalpolitik, No. 86.

Lee, A. T. (1999) "Self-employment and Earnings Among Migrants in Australia," International Migration, 37 (2): $383-$ 412.

Lückgen, I. D. Oberschachtsiek, R. Sternberg and J. Wagner (2004) Nascent Entrepreneurs in German Regions:Evidence from the Regional Entrepreneurship Monitor (REM), IZA Discussion Paper No. 1394.

Lukeš, M., and J. Zouhar. 2013. "No Experience? No Problem-It's All About Yourself: Factors Influencing Nascent Entrepreneurship Outcomes.” Ekonomický Časopis 61 (9): 934-950.

Martin, R. L. (2012) Regional economic resilience, hysteresis and recessionary shocks, Journal of Economic Geography, 12: 1-32.

Martin, R., P. Sunley, B. Gardiner and P. Tyler (2016) How Regions React to Recessions: Resilience and the Role of Economic Structure. Regional Studies, v. 50, p.561-585

Massey, C. (2016) "Immigration quotas and immigrant selection." Explorations in Economic History, 60: 21-40.

Mather, M., N. Mazar, M. Gorlick, N. Lighthall, R. Nichole R.; J. Burgeno, A. Schoeke and D. Ariely (2012) Risk preferences and aging: The "certainty effect" in older adults' decision making, Psychology and Aging, 27(4): 801-816.

Mises, L. (1949) Human Action, New Haven: Yale University Press, 1949

Nina-Pazarzi, E. and M. Giannacourou (2005) Female Employment and Entrepreneurship: Career Choice Trends in Greece, European Research Studies, Volume VIII, Issue (3-4): 59 - 73.

Obschonka, M., R. K. Silbereisen, and E. Schmitt-Rodermund. 2011. "Successful Entrepreneurship as Developmental Outcome." European Psychologist 16 (3): 174-186.

OECD (2015) The Missing Entrepreneurs - Polices for Self-Employment and Entrepreneurship, OECD/European Union 2015.

Pelger, I. (2011) Gender, Investment Financing and Credit Constraints, Munich Discussion Paper No. 2011-22.

Pilkovaa, A., M. Holienkaa and J. Rehaka (2014) Senior entrepreneurship in the perspective of European entrepreneurial environment, Procedia Economics and Finance, 12: 523 - 532.

Rawls, J. (1971) A Theory of Justice, Harvard University Press.

Remoundou, K., M. Gkartzios and G. Garrod (2016) Conceptualizing Mobility in Times of Crisis: Towards Crisis-Led Counterurbanization?, Regional Studies, 50(10): 1663-1674.

Rodriguez-Pose, A. (2013) “Do institutions matter for regional development?”, Regional Studies, 47(7): 1034-1047.

Rusinovic, K. (2008) Moving between markets? Immigrant entrepreneurs in different markets. International Journal of Entrepreneurial Behaviour Research,14(6):440-454.

Schumpeter, J. A. (1947) “The Creative Response in Economic History," The Journal of Economic History, 7 (2): 149159.

Schumpeter, J.A. (1934), The Theory of Economic Development: An Inquiry into Profits, Capital, Credit, Interest, and the Business Cycle, Cambridge, MA: Harvard University Press. 
Shackle, G.L.S. (1949[1952]) Expectation in Economics, University Press: Cambridge.

Shane, S., E. A. Locke, and C. J. Collins (2003) "Entrepreneurial Motivation”, Human Resource Management Review 13 (2): 257-279.

Shapero, A. (1982) 'Social dimensions of entrepreneurship', in Kent, C.A. et al. (Eds.): The Encyclopedia of Entrepreneurship, pp.72-89, Prentice-Hall, Englewood Cilffs, NJ.

Simoes, N., N. Crespo, and S. B. Moreira (2016) "Individual Determinants of Self-employment Entry: What Do We Really Know?” Journal of Economic Surveys 30 (4): 783-806.

Sorgner, A., and M. Fritsch (2017) "Entrepreneurial Career Paths: Occupational Context and the Propensity to Become Self-employed." Small Business Economics, in print.

Steyaert, C. and J. Katz (2004) Reclaiming the space of entrepreneurship in society: geographical, discursive and social dimensions, Entrepreneurship \& Regional Development, 16(3): 179-196.

Tubadji, A. (2013) Culture-Based Development: culture and institutions - economic development in the regions of Europe. Journal of Society Social Science 5(4): 355 - 391.

Tubadji, A. (2012) Culture Based Development - culture as an encompassing economic factor: empirical evidence for Germany. International Journal of Social Economics, 39(9): 690-703.

Tubadji, A., V. Angelis and P. Nijkamp (2016) Cultural Hysteresis, Entrepreneurship and Economic Crisis: An Analysis of Buffers to Unemployment after Economic Shocks, Cambridge Journal of Regions, Economy and Society, forthcoming.

Van Auken, H., F. L. Fry, and P. Stephens (2006) “The Influence of Role Models on Entrepreneurial Intentions.” Journal of Developmental Entrepreneurship 11 (02): 157-167.

Van der Sluis, J., M. Van Praag, and W. Vijverberg (2008) "Education and Entrepreneurship Selection and Performance: A Review of the Empirical Literature," Journal of Economic Surveys 22 (5): 795-841.

Wagner, J. (2004) What a Difference a Y Makes - Female and Male Nascent Entrepreneurs in Germany, IZA Discussion Paper No. 1134.

Wagner, J. (2005) Nascent Necessity and Opportunity Entrepreneurs in Germany Evidence from the Regional Entrepreneurship Monitor (REM), University of Lüneburg, Working Paper Series in Economics, No. 10.

Weber, M. (1905) The Protestant Ethic and the Spirit of Capitalism. New York: Routledge.

Wennberg, K., S. Pathak, and E. Autio (2013) "How Culture Moulds the Effects of Self-efficacy and Fear of Failure on Entrepreneurship", Entrepreneurship and Regional Development, 25 (9-10): 756-780.

Wyrwich, M., Stuetzer, M. and Sternberg, R. (2016) "Entrepreneurial role models, fear of failure, and institutional approval of entrepreneurship: a tale of two regions", Small Business Economics, 46: 467-492.

Zhao, H., Seibert, S.E. and Lumpkin G.T. (2010) 'The relationship of personality to entrepreneurial intentions and performance: a meta-analytic review', Journal of Management, 36(2):381-404. 
Table 1: Descriptive Statistics - All Dataset

\begin{tabular}{|c|c|c|c|c|c|c|c|c|c|c|}
\hline \multirow[t]{2}{*}{ Variable } & \multicolumn{5}{|c|}{ GREECE } & \multicolumn{5}{|c|}{ GERMANY } \\
\hline & Obs & Mean & Std. Dev. & Min & Max & Obs & Mean & Std. Dev. & Min & Max \\
\hline entr_owner & 15909 & 0.21 & 0.41 & 0 & 1 & 39939 & 0.11 & 0.32 & 0 & 1 \\
\hline entr_newpl & 14979 & 0.14 & 0.35 & 0 & 1 & 39420 & 0.08 & 0.27 & 0 & 1 \\
\hline fear & 11208 & 0.56 & 0.50 & 0 & 1 & 26042 & 0.41 & 0.49 & 0 & 1 \\
\hline female & 15938 & 0.51 & 0.50 & 0 & 1 & 41786 & 0.54 & 0.50 & 0 & 1 \\
\hline age & 15938 & 41 & 13.19 & 18 & 64 & 41786 & 44 & 14.91 & 14 & 95 \\
\hline young_15_24 & 15938 & 0.14 & 0.34 & 0 & 1 & 41786 & 0.12 & 0.33 & 0 & 1 \\
\hline young_25_34 & 15938 & 0.22 & 0.42 & 0 & 1 & 41786 & 0.15 & 0.35 & 0 & 1 \\
\hline young1 fear & 11208 & 0.08 & 0.26 & 0 & 1 & 26042 & 0.04 & 0.20 & 0 & 1 \\
\hline young 2 fear & 11208 & 0.13 & 0.33 & 0 & 1 & 26042 & 0.07 & 0.26 & 0 & 1 \\
\hline invest & 13938 & 0.03 & 0.16 & 0 & 1 & 35209 & 0.03 & 0.17 & 0 & 1 \\
\hline incentive & 13938 & 0.16 & 0.36 & 0 & 1 & 35209 & 0.14 & 0.34 & 0 & 1 \\
\hline hc_gem & 13938 & 0.37 & 0.48 & 0 & 1 & 35209 & 0.44 & 0.50 & 0 & 1 \\
\hline a_equal & 13938 & 0.47 & 0.50 & 0 & 1 & 35209 & 0.36 & 0.48 & 0 & 1 \\
\hline a_nbgood & 13938 & 0.47 & 0.50 & 0 & 1 & 35209 & 0.32 & 0.47 & 0 & 1 \\
\hline a_nbstatus & 13938 & 0.49 & 0.50 & 0 & 1 & 35209 & 0.46 & 0.50 & 0 & 1 \\
\hline a_nbmedia & 13938 & 0.28 & 0.45 & 0 & 1 & 35209 & 0.30 & 0.46 & 0 & 1 \\
\hline ai_network & 13938 & 0.29 & 0.45 & 0 & 1 & 35209 & 0.25 & 0.43 & 0 & 1 \\
\hline
\end{tabular}

Authors' calculations.

Table 2: Descriptive Statistics - Fear-of-Failure per Country

\begin{tabular}{|c|c|c|c|}
\hline \multicolumn{1}{|c|}{ Variable } & \multicolumn{3}{|c|}{ FEAR } \\
\hline & All ages & Young_15_24 & Young_25_35 \\
\hline All & & & \\
\hline GREECE & 56 & 57 & 55 \\
\hline GERMANY & 41 & 38 & 44 \\
\hline Before crises 2007 & & & \\
\hline GREECE & 55 & 58 & 55 \\
\hline GERMANY & 42 & 38 & 44 \\
\hline After crises 2007 & & & \\
\hline GREECE & 57 & 57 & 55 \\
\hline GERMANY & 41 & 37 & 43 \\
\hline
\end{tabular}

Authors' calculations. 
Table 3: Correlations between Main Variables per Country

\begin{tabular}{|c|c|c|c|c|c|c|c|}
\hline & \multicolumn{7}{|c|}{ Correlation Coefficients } \\
\hline & & entr_owner & entr_owner & female & fear & young_15_ & $25 \_3$ \\
\hline \multicolumn{8}{|l|}{ All } \\
\hline \multirow{6}{*}{ GREECE } & entr_owner & 1 & & & & & \\
\hline & entr_newpl & -0.03 & 1 & & & & \\
\hline & female & -0.16 & -0.14 & 1 & & & \\
\hline & fear & -0.08 & -0.12 & 0.10 & 1 & & \\
\hline & young_15_24 & -0.12 & 0.07 & -0.02 & 0.01 & 1 & \\
\hline & young_25_34 & -0.02 & 0.09 & -0.02 & -0.01 & -0.20 & 1 \\
\hline \multirow{6}{*}{ GERMANY } & entr_owner & 1 & & & & & \\
\hline & entr_newpl & 0.10 & 1 & & & & \\
\hline & female & -0.10 & -0.10 & 1 & & & \\
\hline & fear & -0.18 & -0.16 & 0.13 & 1 & & \\
\hline & young_15_24 & -0.11 & 0.05 & -0.04 & -0.03 & 1 & \\
\hline & young_25_34 & -0.04 & 0.09 & -0.02 & 0.02 & -0.16 & 1 \\
\hline
\end{tabular}

Authors' calculations. 
Table 4: Individual Propensity to Business Ownership - marginal effects, probit model estimations

\begin{tabular}{|c|c|c|c|c|c|c|}
\hline \multirow{3}{*}{$\begin{array}{l}\text { country } \\
\text { dep. var. }\end{array}$} & \multicolumn{3}{|c|}{ GREECE } & \multicolumn{3}{|c|}{ GERMANY } \\
\hline & \multicolumn{6}{|c|}{ entr_owner } \\
\hline & $\mathrm{dy} / \mathrm{dx}$ & z-value & & $\mathrm{dy} / \mathrm{dx}$ & z-value & \\
\hline fear & -0.034 & -3.49 & $* *$ & -0.096 & -17.89 & $* * *$ \\
\hline female & -0.093 & -9.52 & $* * *$ & -0.047 & -9.35 & $* * *$ \\
\hline young_15_24 & -0.148 & -4.14 & $* * *$ & -0.189 & -8.89 & $* * *$ \\
\hline young_25_35 & -0.072 & -2.77 & $* *$ & -0.070 & -4.67 & $* * *$ \\
\hline young1_fear & 0.048 & 1.79 & & 0.069 & 3.53 & $* * *$ \\
\hline young2 fear & -0.001 & -0.04 & & -0.007 & -0.51 & \\
\hline young1_female & 0.015 & 0.55 & & -0.013 & -0.72 & \\
\hline young 2 female & 0.031 & 1.58 & & 0.030 & 2.35 & \\
\hline age & 0.000 & 0.26 & & -0.001 & -4.29 & $* * *$ \\
\hline hc_gem & -0.025 & -3.06 & $* *$ & 0.048 & 10.18 & *** \\
\hline invest & -0.054 & -2.78 & $* *$ & -0.001 & -0.14 & \\
\hline incentive & -0.029 & -3.01 & $* *$ & -0.003 & -0.63 & \\
\hline a_equal & 0.143 & 13.38 & $* * *$ & 0.119 & 21.67 & $* * *$ \\
\hline a_nbgood & 0.128 & 11.76 & $* * *$ & 0.044 & 7.30 & *** \\
\hline a_nbstatus & 0.128 & 11.50 & $* * *$ & 0.104 & 17.32 & $* * *$ \\
\hline a_nbmedia & 0.072 & 6.38 & $* * *$ & 0.081 & 13.98 & $* * *$ \\
\hline ai_network & 0.047 & 4.80 & *** & 0.060 & 11.72 & *** \\
\hline a1_young1 & -0.053 & -1.71 & & -0.069 & -3.48 & $* * *$ \\
\hline a2_young1 & -0.002 & -0.06 & & -0.007 & -0.32 & \\
\hline a3_young1 & 0.004 & 0.14 & & 0.036 & 1.57 & \\
\hline a4_young1 & -0.040 & -1.25 & & -0.024 & -1.18 & \\
\hline a5_young1 & -0.048 & -1.78 & & -0.006 & -0.36 & \\
\hline a1_young 2 & 0.040 & 1.88 & & -0.043 & -3.16 & $* *$ \\
\hline a2_young 2 & 0.003 & 0.12 & & 0.014 & 0.97 & \\
\hline a3_young2 & 0.020 & 0.91 & & -0.011 & -0.75 & \\
\hline a4_young 2 & -0.065 & -2.93 & $* *$ & -0.023 & -1.60 & \\
\hline a5_young 2 & -0.013 & -0.69 & & -0.017 & -1.37 & \\
\hline Year FE & \multicolumn{3}{|c|}{ YES } & \multicolumn{3}{|c|}{ YES } \\
\hline $\mathrm{N}$ & \multicolumn{3}{|c|}{9860} & \multicolumn{3}{|c|}{22074} \\
\hline chi2 & \multicolumn{3}{|c|}{$(33)=2690.36$} & \multicolumn{3}{|c|}{$(32)=4788.06$} \\
\hline Prob $>$ chi 2 & \multicolumn{3}{|c|}{0.0000} & \multicolumn{3}{|c|}{0.0000} \\
\hline Pseudo R2 & \multicolumn{3}{|c|}{0.22} & \multicolumn{3}{|c|}{0.24} \\
\hline
\end{tabular}

Authors' calculations. 


\section{Table 5: Crisis Effect on Individual Propensity to Business Ownership - marginal effects, probit model estimations}

\begin{tabular}{|c|c|c|c|c|c|c|c|c|c|c|c|c|}
\hline \multirow{4}{*}{\begin{tabular}{|l|} 
country \\
dep. var. \\
\end{tabular}} & \multicolumn{6}{|c|}{ GREECE } & \multicolumn{6}{|c|}{ GERMANY } \\
\hline & \multicolumn{3}{|c|}{ befre 2007} & \multicolumn{3}{|c|}{ after 2007} & \multicolumn{3}{|c|}{ befre 2007} & \multicolumn{3}{|c|}{ after 2007} \\
\hline & \multicolumn{12}{|c|}{ entr_owner } \\
\hline & $\mathrm{dy} / \mathrm{dx}$ & z-value & & $\mathrm{dy} / \mathrm{dx}$ & z-value & & $\mathrm{dy} / \mathrm{dx}$ & z-value & & $\mathrm{dy} / \mathrm{dx}$ & z-value & \\
\hline fear & -0.010 & -0.67 & & -0.049 & -3.90 & $* * *$ & -0.085 & -11.13 & $* * *$ & -0.103 & -13.78 & $* * *$ \\
\hline female & -0.065 & -4.24 & *** & -0.109 & -8.74 & $* * *$ & -0.042 & -6.01 & $* * *$ & -0.047 & -6.74 & $* * *$ \\
\hline young_15_24 & -0.049 & -1.00 & & -0.219 & -4.22 & $* * *$ & -0.163 & -6.30 & $* * *$ & -0.191 & -5.49 & *** \\
\hline young_25_35 & -0.012 & -0.31 & & -0.116 & -3.30 & $* *$ & -0.062 & -3.13 & $* *$ & -0.068 & -3.04 & $* *$ \\
\hline young1 fear & 0.080 & 2.12 & * & 0.016 & 0.42 & & 0.085 & 3.61 & $* * *$ & 0.025 & 0.73 & \\
\hline young2 fear & 0.006 & 0.20 & & -0.005 & -0.19 & & -0.011 & -0.59 & & -0.003 & -0.13 & \\
\hline young1_female & -0.047 & -1.25 & & 0.061 & 1.57 & & -0.017 & -0.74 & & -0.010 & -0.34 & \\
\hline young2 female & 0.030 & 1.04 & & 0.037 & 1.41 & & 0.017 & 1.03 & & 0.038 & 2.08 & \\
\hline age & 0.002 & 2.23 & * & -0.001 & -1.24 & & -0.002 & -4.80 & $* * *$ & 0.000 & -0.59 & \\
\hline hc_gem & -0.008 & -0.62 & & -0.032 & -2.96 & $* *$ & 0.029 & 4.09 & $* * *$ & 0.059 & 9.24 & $* * *$ \\
\hline invest & -0.073 & -2.62 & $* *$ & -0.036 & -1.40 & & -0.035 & -3.22 & $* *$ & 0.034 & 2.57 & * \\
\hline incentive & -0.050 & -3.49 & $* * *$ & -0.010 & -0.79 & & -0.005 & -0.68 & & -0.002 & -0.21 & \\
\hline a_equal & 0.210 & 12.41 & $* * *$ & 0.102 & 7.49 & $* * *$ & 0.122 & 15.50 & $* * *$ & 0.108 & 14.48 & $* * *$ \\
\hline a_nbgood & 0.124 & 6.88 & $* * *$ & 0.124 & 8.99 & $* * *$ & 0.053 & 6.03 & $* * *$ & 0.035 & 4.22 & *** \\
\hline a_nbstatus & 0.133 & 7.24 & $* * *$ & 0.118 & 8.38 & $* * *$ & 0.110 & 13.35 & $* * *$ & 0.089 & 10.65 & *** \\
\hline a_nbmedia & 0.062 & 3.35 & $* *$ & 0.073 & 5.15 & $* * *$ & 0.101 & 12.28 & $* * *$ & 0.062 & 7.70 & *** \\
\hline ai_network & 0.013 & 0.81 & & 0.064 & 5.04 & $* * *$ & 0.039 & 5.39 & $* * *$ & 0.076 & 10.68 & $* * *$ \\
\hline a1_young1 & -0.061 & -1.32 & & -0.050 & -1.19 & & -0.098 & -3.92 & $* * *$ & -0.024 & -0.76 & \\
\hline a2_young1 & 0.031 & 0.63 & & -0.025 & -0.57 & & -0.012 & -0.44 & & -0.004 & -0.13 & \\
\hline a3_young1 & -0.073 & -1.58 & & 0.068 & 1.50 & & 0.060 & 2.15 & * & -0.005 & -0.14 & \\
\hline a4_young1 & -0.016 & -0.36 & & -0.075 & -1.69 & & -0.050 & -2.02 & * & -0.006 & -0.18 & \\
\hline a5_young1 & -0.004 & -0.12 & & -0.063 & -1.63 & & -0.008 & -0.37 & & -0.008 & -0.28 & \\
\hline a1_young2 & -0.055 & -1.71 & & 0.089 & 3.20 & $* *$ & -0.036 & -1.92 & & -0.049 & -2.58 & * \\
\hline a2_young2 & 0.026 & 0.81 & & -0.011 & -0.38 & & 0.009 & 0.44 & & 0.014 & 0.69 & \\
\hline a3_young2 & 0.038 & 1.13 & & 0.002 & 0.06 & & -0.023 & -1.18 & & 0.004 & 0.17 & \\
\hline a4_young 2 & -0.063 & -1.91 & & -0.048 & -1.62 & & -0.021 & -1.07 & & -0.029 & -1.41 & \\
\hline a5_young 2 & -0.016 & -0.56 & & 0.000 & -0.01 & & 0.006 & 0.35 & & -0.040 & -2.24 & \\
\hline year FE & \multicolumn{3}{|c|}{ YES } & \multicolumn{3}{|c|}{ YES } & \multicolumn{3}{|c|}{ YES } & \multicolumn{3}{|c|}{ YES } \\
\hline chi2 & \multicolumn{3}{|c|}{$(29)=1429.12$} & \multicolumn{3}{|c|}{$(29)=1368.39$} & \multicolumn{3}{|c|}{$(29)=2948.89$} & \multicolumn{3}{|c|}{$(29)=2008.3$} \\
\hline Prob $>$ chi 2 & \multicolumn{3}{|c|}{0.0000} & \multicolumn{3}{|c|}{0.0000} & \multicolumn{3}{|c|}{0.0000} & \multicolumn{3}{|c|}{0.0000} \\
\hline Pseudo R-sq & \multicolumn{3}{|c|}{0.30} & \multicolumn{3}{|c|}{0.19} & \multicolumn{3}{|c|}{0.31} & \multicolumn{3}{|c|}{0.19} \\
\hline $\mathrm{N}$ & \multicolumn{3}{|c|}{3886} & & 5974 & & & 10377 & & & 11697 & \\
\hline
\end{tabular}

Authors' calculations. 


\section{Appendix 1}

\begin{tabular}{|c|c|c|c|c|c|c|}
\hline & Variable & Definition & Observations & Mean & Min. & Max \\
\hline & entr_owner & $\begin{array}{l}\text { Dummy variable = } 1 \text { if 'Yes' as answer to GEM question Q2A, } \\
\text { answering to variable 'ownmge', referring to being self-identified }\end{array}$ & 55848 & 0.14 & 0 & 1 \\
\hline $\begin{array}{c}\text { outcome } \\
\text { vars }\end{array}$ & entr_newpl & $\begin{array}{l}\text { Dummy variable = } 1 \text { if 'Yes' as answer to GEM question Q3A, } \\
\text { answering to variable 'futsup', referring to those expecting to } \\
\text { start (alone or with others) a new business }\end{array}$ & 54399 & 0.09 & 0 & 1 \\
\hline $\begin{array}{c}\text { explanatory } \\
\text { var }\end{array}$ & fear & $\begin{array}{l}\text { Dummy variable = } 1 \text { if the interviewee has answered 'Yes' to the } \\
\text { GEM question Qi4: "Would fear-of-failure prevent you from }\end{array}$ & 37250 & 0.46 & 0 & 1 \\
\hline \multirow{26}{*}{ control vars } & female & $\begin{array}{l}\text { Dummy variable = } 1 \text { when GEM question DEMA. 'What is your } \\
\text { gender' is answered as 'female'. }\end{array}$ & 57724 & 0.53 & 0 & 1 \\
\hline & young_15_24 & $\begin{array}{l}\text { Dummy variable = } 1 \text { when GEM question DEMB.'What is your current } \\
\text { age in years?' is answered with a number ranging between } 15-24 \\
\text { years old. }\end{array}$ & 49147 & 0.14 & 0 & 1 \\
\hline & young_25_35 & $\begin{array}{l}\text { Dummy variable = } 1 \text { when GEM question DEMB. 'What is your current } \\
\text { age in years?' is answered with a number ranging between } 25 \text { up to } \\
35 \text { years old. }\end{array}$ & 49147 & 0.17 & 0 & 1 \\
\hline & young1_fear & Interaction term between young_15_24 and variable fear & 31983 & 0.06 & 0 & 1 \\
\hline & young2 fear & Interaction term between young_ $25 \_35$ and variable fear & 31983 & 0.09 & 0 & 1 \\
\hline & young1_female & Interaction term between young_15_24 and variable female & 49147 & 0.07 & 0 & 1 \\
\hline & young 2 female & Interaction term between young_ $25 \_35$ and variable female & 49147 & 0.08 & 0 & 1 \\
\hline & age & $\begin{array}{l}\text { Equal to GEM variable DEMB.'What is your current age in years?' } \\
\text { which is answered in years. }\end{array}$ & 57724 & 43.00 & 14 & 95 \\
\hline & $h c \_g e m$ & $\begin{array}{l}\text { Dummy variable equal to } 1 \text { when GEM variable GEMEDUC, reporting } \\
\text { harmonized educational attainment categories among interviewees } \\
\text { has one of the following answers: Post secondary or Graduate } \\
\text { experience; when the answer to the question is N/A the } \\
\text { observations are excluded from estimations. }\end{array}$ & 49147 & 0.42 & 0 & 1 \\
\hline & invest & $\begin{array}{l}\text { Dummy variable = } 1 \text { if the GEM question Q4A. 'Have you, in the past } \\
\text { three years, personally provided funds for a new business' is } \\
\text { answered with 'Yes' }\end{array}$ & 49147 & 0.03 & 0 & 1 \\
\hline & incentive & $\begin{array}{l}\text { Dummy variable = } 1 \text { if the GEM question Qi2. 'In the next six } \\
\text { months, will there be good opportunities for starting a business' is } \\
\text { answered with 'Yes' }\end{array}$ & 49147 & 0.14 & 0 & 1 \\
\hline & a_equal & $\begin{array}{l}\text { Dummy variable = } 1 \text { if the GEM question Qi5. 'In my country, most } \\
\text { people would prefer that everyone had a similar standar' is } \\
\text { answered with 'Yes' }\end{array}$ & 49147 & 0.39 & 0 & 1 \\
\hline & a_nbgood & $\begin{array}{l}\text { Dummy variable = } 1 \text { if the GEM question Qi6. ' In my country, most } \\
\text { people consider starting a new business a desirable activity' is } \\
\text { answered with 'Yes' }\end{array}$ & 49147 & 0.36 & 0 & 1 \\
\hline & a_nbstatus & $\begin{array}{l}\text { Dummy variable = } 1 \text { if the GEM question Qi7. ' In my country, those } \\
\text { successful at starting a new business have a high level of status ' is } \\
\text { answered with 'Yes' }\end{array}$ & 49147 & 0.47 & 0 & 1 \\
\hline & a_nbmedia & $\begin{array}{l}\text { Dummy variable = } 1 \text { if the GEM question Qi8. 'In my country, you will } \\
\text { often see stories in the public media about successful entrepreneurs' } \\
\text { is answered with 'Yes' }\end{array}$ & 49147 & 0.30 & 0 & 1 \\
\hline & ai_network & $\begin{array}{l}\text { Dummy variable = } 1 \text { if the GEM question Qi1. 'Do you know someone } \\
\text { personally who started a business in the past } 2 \text { years? ' is answered } \\
\text { with 'Yes' }\end{array}$ & 49147 & 0.26 & 0 & 1 \\
\hline & a1_young1 & Interaction term between young_15_24 and a_equal & 49147 & 0.05 & 0 & 1 \\
\hline & a2_young1 & Interaction term between young_15_24 and a_nbgood & 49147 & 0.06 & 0 & 1 \\
\hline & a3_young1 & Interaction term between young_15_24 and a_nbstatus & 49147 & 0.07 & 0 & 1 \\
\hline & a4_young1 & Interaction term between young_15_24 and a_nbmedia & 49147 & 0.04 & 0 & 1 \\
\hline & a5_young 1 & Interaction term between young_15_24 and a_nbmedia & 49147 & 0.04 & 0 & 1 \\
\hline & a1_young2 & Interaction term between young_25_35 and a_equal & 49147 & 0.07 & 0 & 1 \\
\hline & a2_young2 & Interaction term between young_25_35 and a_nbgood & 49147 & 0.07 & 0 & 1 \\
\hline & a3_young2 & Interaction term between young_25_35 and a_nbstatus & 49147 & 0.08 & 0 & 1 \\
\hline & a4_young2 & Interaction term between young_25_35 and a_nbmedia & 49147 & 0.05 & 0 & 1 \\
\hline & a5_young 2 & Interaction term between young_25_35 and a_nbmedia & 49147 & 0.06 & 0 & 1 \\
\hline
\end{tabular}

